\title{
Does mating negatively affect female immune defences in insects?
}

\author{
Keiko Oku $^{1, *}$, Tom A.R. Price ${ }^{2}$ and Nina Wedell ${ }^{1}$ \\ ${ }^{1}$ Centre for Ecology and Conservation, University of Exeter, Cornwall Campus, Penryn TR10 9FE, \\ UK \\ ${ }^{2}$ Institute of Integrative Biology, University of Liverpool, Biosciences Building, Crown Street, \\ Liverpool L69 7ZB, UK
}

Submitted: July 26, 2018. Final revision received: January 25, 2019. Accepted: February 4, 2019

\begin{abstract}
Immunity is an important mechanism of protection against pathogens and parasites. One factor that can influence immunity is mating. During mating, male-derived materials are transferred to females, and the physical contact also involves the potential risk of sexually transmitted infections, and wounding. Thus, mating can challenge a female's immune system. This review focuses on exploring how immunity and mating interact in female insects. Although mating has been shown to cause female immune responses in several species, the responses do not always match the observed resistance to pathogens/parasites. Mating up-regulates female immune responses while female resistance is reduced compared to virgin females in some species, and vice versa in other taxa. We discuss why mismatches occur and why post-mating female resistance differs among species, and suggest that measured immune responses may not correlate with female resistance. Also, the mating system will play a major role. Polyandrous mating systems can generate intense post-mating sexual conflict, which can impose high costs of mating on females. Reduced female post-mating resistance may be due to direct suppression of female immunity by males. Alternatively, polyandry may increase the risk of sexually transmitted infections. If this is the major factor driving female post-mating resistance, females of polyandrous species should have higher post-mating immunity. To date, there are insufficient numbers of studies to fully answer the question 'does mating negatively affect female immune defences in insects?' To elucidate the links between immunity and mating in females, we need more studies in more species with varied mating systems.
\end{abstract}

\section{Keywords}

Immune function; immune response; mating; sexual conflict; timing of measurement

*) Corresponding author; e-mail: k.oku@exeter.ac.uk 


\section{Introduction}

Immunity is an important mechanism for organisms to protect themselves against pathogens and parasites. Hence, immunity is an important determinant of an individual's fitness (Zuk \& Stoehr, 2002; Lazzaro \& Little, 2009). However, immunity is costly (Sheldon \& Verhulst, 1996; Lochmiller \& Deerenberg, 2000; Zuk $\&$ Stoehr, 2002). Because resources are limited, trade-offs between immunity and other life-history traits will invariably occur (Sheldon \& Verhulst, 1996; Zuk \& Stoehr, 2002). In addition, life history traits often increase or decrease the likelihood of exposure to pathogens, thereby altering the relative importance of immunity. One factor that can influence immune defences is mating. This review focuses on understanding how immunity and mating interact in females.

Mating is a situation where self and non-self agents interact. During mating, foreign materials (e.g., sperm and other ejaculate components) are transferred to females, and male genitalia can also directly wound female genitalia and the reproductive tract (e.g., Crudgington \& Siva-Jothy, 2000; Blanckenhorn et al., 2002; Kamimura, 2007). Moreover, the physical contact of mating involves the potential risk of sexually transmitted infections or parasites (Smith \& Dobson, 1992; Hurst et al., 1995; Knell \& Webberley, 2004; Whitlow, 2004). Thus, mating frequently challenges the female's immune system. If the act of mating up-regulates the females' immune system, other life-history traits such as fecundity or longevity may be compromised due to trade-offs. On the other hand, mating also changes females' physiology, for example by stimulating egg maturation (South \& Lewis, 2011). These physiological changes are often under endocrine control (e.g., juvenile hormone) (Schwenke et al., 2016), and these hormones are also involved in immunity (e.g., Rolff \& Siva-Jothy, 2002; Chen et al., 2016; Schwenke \& Lazzaro, 2017). For example, mating induces the release of juvenile hormone, which down-regulates enzyme activity involved in the humoral immune system of the mealworm beetle Tenebrio molitor Linnaeus, 1758 (Rolff \& Siva-Jothy, 2002). Furthermore, juvenile hormone promotes oocyte maturation of mated females of the fruit fly Drosophila melanogaster Meigen, 1830 (Soller et al., 1999), whereas it suppresses their resistance to bacterial infection (Schwenke \& Lazzaro, 2017). It is therefore possible that females' immune systems are down-regulated by mating if both reproduction and the immune system are mediated by the same hormone that acts antagonistically. This in turn may make mated females more vulnerable to pathogens and parasites. So how does the females' immune system respond to mating?

When considering the immune system, it is important to discriminate between a response to being infected per se and an effective immune response to a pathogen or parasite (Zuk \& Stoehr, 2002). Although mating has been shown to elicit a female immune response in several invertebrates (Lawniczak et al., 2007; Morrow \& Innocenti, 2012), the female immune response does not tell us whether female immunity confers resistance or makes them susceptible to pathogens and/or parasites after mating. As the immune system consists of multiple mechanisms and pathways 


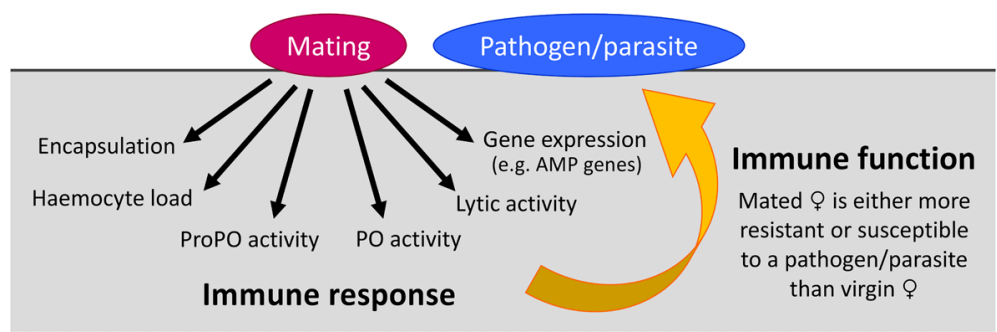

Figure 1. A schematic outline of post-mating responses, showing the distinction between immune response and immune function. Immune responses are examples listed in table 1 . The grey background indicates the inside of an organism's body. Abbreviations: AMP genes, antimicrobial peptide genes; PO, phenoloxidase; ProPO, prophenoloxidase.

which respond to specific foreign materials (Gillespie et al., 1997; Lemaitre \& Hoffmann, 2007), it is possible that an observed post-mating female immune response is not related to actual resistance to a particular pathogen or a parasite. It is therefore necessary to consider how the female immune response contributes to their immune defence. To distinguish female immune response to mating or infection/wounding involved in mating from female actual resistance to pathogens/parasites, we will describe the former as the 'post-mating immune response' and the latter as the 'post-mating immune function'. That is, post-mating immune response indicates observed phenomena caused by mating or infection/wounding involved in mating, whereas post-mating immune function represents effects of mating on subsequent female resistance to pathogens/parasites (fig. 1).

To examine the links between immunity and mating, we need model systems in which both immunity and mating are relatively well understood, and ideally can be manipulated experimentally. Insects are suitable organisms to study the links between immunity and mating because a large body of research on immunity (Schmid-Hempel, 2005; Rolff \& Reynolds, 2009) and mating (Thornhill \& Alcock, 1983; Shuker \& Simmons, 2014) has been carried out in this group. Here, we review studies investigating the effects of mating on female immunity in insects and show that measured immune responses to mating do not always match female immune function. We then discuss whether mating tends to have a negative effect on female immune defences or not.

\section{Post-mating immune response}

In terms of gene expression, mating is well known to change female transcription levels (Lawniczak \& Begun, 2004; McGraw et al., 2004; Mack et al., 2006; Innocenti \& Morrow, 2009; Rogers et al., 2008; Gomulski et al., 2012). However, the evidence of how mating alters expression of immune genes in females is mixed (table 1). Mating activates expression of immune genes in some species (e.g., fruit fly D. melanogaster: Lawniczak \& Begun, 2004; McGraw et al., 2004; Kapelnikov et al., 2008; Innocenti \& Morrow, 2009; bumblebee Bombus terrestris Linnaeus, 
Table 1.

A list of studies investigating female post-mating immune responses in insects.

\begin{tabular}{|c|c|c|c|c|c|}
\hline \multicolumn{2}{|c|}{ Insect species } & \multirow{2}{*}{$\begin{array}{l}\begin{array}{l}\text { Measurement(s) } \\
\text { after mating }\end{array} \\
2,36 \mathrm{~h} \& 7 \mathrm{~d}\end{array}$} & \multirow{2}{*}{$\begin{array}{l}\text { Immune } \\
\text { indicator(s) } \\
\text { Phenoloxidase } \\
\text { activity }\end{array}$} & \multicolumn{2}{|c|}{ Response Reference(s) } \\
\hline Ant & $\begin{array}{l}\text { Formica } \\
\text { paralugubris }\end{array}$ & & & $\downarrow$ & Castella et al. (2009) \\
\hline & Lasius niger & $\begin{array}{l}24 \mathrm{~h}, 1,2 \mathrm{w} \& \\
4 \mathrm{~m}\end{array}$ & $\begin{array}{l}\text { Prophenoloxidase } \\
\text { activity } \\
\text { Phenoloxidase } \\
\text { activity }\end{array}$ & $\begin{array}{c}\downarrow,=, \uparrow, \downarrow \\
=\end{array}$ & Dávila et al. (2015) \\
\hline & $\begin{array}{l}\text { Acromyrmex } \\
\text { echinatior }\end{array}$ & ca $4 \mathrm{~m}^{\mathrm{a}}$ & $\begin{array}{l}\text { Prophenoloxidase } \\
\text { activity } \\
\text { Phenoloxidase } \\
\text { activity }\end{array}$ & $\begin{array}{l}\downarrow \\
=\end{array}$ & Dávila et al. (2015) \\
\hline & $\begin{array}{l}\text { Atta } \\
\text { colombica }\end{array}$ & $24 \mathrm{~h}$ & $\begin{array}{l}\text { Prophenoloxidase } \\
\text { activity } \\
\text { Phenoloxidase } \\
\text { activity }\end{array}$ & $\begin{array}{l}\uparrow \\
\downarrow\end{array}$ & Dávila et al. (2015) \\
\hline Beetle & $\begin{array}{l}\text { Tenebrio } \\
\text { molitor }\end{array}$ & $24 \mathrm{~h}$ & $\begin{array}{l}\text { Phenoloxidase } \\
\text { activity } \\
\text { Haemocyte load }\end{array}$ & $\downarrow$ & Rolff \& Siva-Jothy (2002) \\
\hline & $\begin{array}{l}\text { Carabus } \\
\text { lefebvrei }\end{array}$ & $2 d$ & $\begin{array}{l}\text { Phenoloxidase } \\
\text { activity } \\
\text { Lytic activity }\end{array}$ & $\begin{array}{l}\downarrow \\
\downarrow\end{array}$ & Giglio et al. (2016) \\
\hline Bumblebee & $\begin{array}{l}\text { Bombus } \\
\text { terrestris }\end{array}$ & $2,6 \& 24 \mathrm{~h}$ & Gene expression & $\uparrow$ & $\begin{array}{l}\text { Barribeau \& } \\
\text { Schmid-Hempel (2017) }\end{array}$ \\
\hline Cricket & $\begin{array}{l}\text { Acheta } \\
\text { domesticus }\end{array}$ & $3 w^{b}$ & $\begin{array}{l}\text { Encapsulation } \\
\text { ability }\end{array}$ & $\downarrow$ & $\begin{array}{l}\text { Bascuñán-García et al. } \\
\text { (2010) }\end{array}$ \\
\hline & $\begin{array}{l}\text { Allonemobius } \\
\text { socius }\end{array}$ & $24 \mathrm{~h}$ & $\begin{array}{l}\text { Haemocyte load } \\
\text { Phenoloxidase } \\
\text { activity } \\
\text { Lytic activity } \\
\text { Encapsulation } \\
\text { ability }\end{array}$ & $\begin{array}{l}\downarrow \\
\uparrow \\
\downarrow \\
\downarrow\end{array}$ & Fedorka et al. (2004) \\
\hline & $\begin{array}{l}\text { Gryllus } \\
\text { texensis }\end{array}$ & $>3 \mathrm{~d}^{\mathrm{b}}$ & $\begin{array}{l}\text { Phenoloxidase } \\
\text { activity }\end{array}$ & $=$ & Shoemaker et al. (2006) \\
\hline Dung fly & $\begin{array}{l}\text { Scathophaga } \\
\text { stercoraria }\end{array}$ & $24 \mathrm{~h}$ & $\begin{array}{l}\text { Phenoloxidase } \\
\text { activity }\end{array}$ & $=$ & $\begin{array}{l}\text { Schwarzenbach et al. } \\
\text { (2005) }\end{array}$ \\
\hline Earwig & $\begin{array}{l}\text { Forficula } \\
\text { auricularia }\end{array}$ & $7 \mathrm{~d} \& 4 \mathrm{~m}^{\mathrm{b}}$ & $\begin{array}{l}\text { Haemocyte load } \\
\text { Phenoloxidase } \\
\text { activity }\end{array}$ & $\begin{array}{c}= \\
=, \downarrow^{\mathrm{c}}\end{array}$ & Vogelweith et al. (2017) \\
\hline Fruit fly & $\begin{array}{l}\text { Drosophila } \\
\text { melanogaster }\end{array}$ & $\begin{array}{l}2 \mathrm{~h} \\
1-3 \mathrm{~h} \\
1-16 \mathrm{~h} \& 1-5 \mathrm{~d} \\
3 \& 27 \mathrm{~h} \\
3 \mathrm{~h} \\
4 \mathrm{~h} \\
6 \mathrm{~h}\end{array}$ & Gene expression & $\uparrow$ & $\begin{array}{l}\text { Lawniczak \& Begun (2004) } \\
\text { McGraw et al. (2004) } \\
\text { Peng et al. (2005) } \\
\text { Fedorka et al. (2007) } \\
\text { Kapelnikov et al. (2008) } \\
\text { Wigby et al. (2008) } \\
\text { Innocenti \& Morrow } \\
\text { (2009) }\end{array}$ \\
\hline
\end{tabular}


Table 1.

(Continued.)

\begin{tabular}{|c|c|c|c|c|c|}
\hline \multicolumn{2}{|c|}{ Insect species } & \multirow{2}{*}{$\begin{array}{l}\begin{array}{l}\text { Measurement(s) } \\
\text { after mating }\end{array} \\
1 \mathrm{~d} \\
2 \& 4 \mathrm{~h}\end{array}$} & \multirow{2}{*}{$\begin{array}{l}\begin{array}{l}\text { Immune } \\
\text { indicator(s) }\end{array} \\
\text { Gene expression }\end{array}$} & \multicolumn{2}{|c|}{ Response Reference(s) } \\
\hline Medfly & Ceratitis & & & $\begin{array}{c}\uparrow=\downarrow^{\mathrm{d}} \\
\downarrow, \uparrow\end{array}$ & $\begin{array}{l}\text { Gomulski et al. (2012) } \\
\text { Msaad Guerfali et al. } \\
\text { (2018) }\end{array}$ \\
\hline Mosquito & $\begin{array}{l}\text { Anopheles } \\
\text { gambiae }\end{array}$ & $2,6 \& 24 \mathrm{~h}$ & Gene expression & $=$ & Rogers et al. (2008) \\
\hline
\end{tabular}

Symbols and letters: $=$, means that the degree of immune responses does not differ between mated and virgin females (i.e., no effects of mating); ${ }^{a}$, after their mating flight; ${ }^{b}$, unclear when and how many times females had mated before measurements; ${ }^{\mathrm{c}}$, age-dependent; phenoloxidase activity significantly increased with age in virgin females but not in mated females; ${ }^{\mathrm{d}}$, the response varied among six immune genes.

1758: Barribeau \& Schmid-Hempel, 2017; medfly Ceratitis capitata (Wiedemann, 1824): Gomulski et al., 2012; Msaad Guerfali et al., 2018) but not in other species (e.g., mosquito Anopheles gambiae Giles, 1902: Rogers et al., 2008). Whole bodies, abdomens, reproductive tracts, and/or heads have been used for immune gene expression analyses. Thus, it is not clear to what extent these differences are due to tissue-specific variation in gene expression. Antimicrobial peptide (AMP) genes in particular, are activated by mating in D. melanogaster (whole bodies: Lawniczak \& Begun, 2004; McGraw et al., 2004; Peng et al., 2005; Fedorka et al., 2007; Innocenti \& Morrow, 2009; abdomens: Wigby et al., 2008; reproductive tract: Kapelnikov et al., 2008). AMPs are produced as a first line of the immune defence against viruses, bacteria, fungi and parasites (Zhang \& Gallo, 2016).

In addition to quantifying the level of immune gene expression, several factors have been measured to assay post-mating immune response in a variety of insect species. These include encapsulation ability, haemocyte load, and/or activity of enzymes, such as prophenoloxidase (proPO), phenoloxidase (PO) and lysozyme (table 1, fig. 1). Encapsulation is a reaction in which multiple layers of haemocytes and/or a coat of melanin encapsulate the invading pathogens (Gillespie et al., 1997), such as fungi (Butt et al., 1988) and parasites (Eslin \& Prévost, 1996, 1998). The degree of melanisation is normally used as a measure of encapsulation ability (e.g., Bascuñan-García et al., 2010). The amount of haemocytes, which represents the number of immunocytes in the haemolymph (Rolff \& Siva-Jothy, 2002), is also used to quantify encapsulation (e.g., Fedorka et al., 2004). Melanotic encapsulation is associated with ProPO and PO activities (Gillespie et al., 1997; Söderhäll \& Cerenius, 1998). In invertebrates, PO exists in the blood in an inactive form ProPO, which is activated by pathogens and wounds (Söderhäll \& Cerenius, 1998). Lysozyme defends against bacterial infection (Gillespie et al., 1997) by hydrolysing the bacterial cell walls and causing bacterial lysis (Ragan et al., 2009). The enzyme activity is expressed as lytic activity (e.g., Fedorka et al., 2004). These immune factors are frequently compared between mated and virgin females (table 1). Relatively higher 
values in mated compared to virgin females indicate that mating up-regulates these aspects of the female immune response. In contrast, when they are lower in mated females, it suggests that mating down-regulates females' immune response.

Examination of these post-mating immune factors also reveals mixed results similar to those shown for gene expression patterns (table 1). Mating down-regulates PO activity in the ant Formica paralugubris Seifert, 1996 (Castella et al., 2009) and the mealworm beetle Tenebrio molitor (Rolff \& Siva-Jothy, 2002), while mating does not affect PO activity in the field cricket Gryllus texensis Cade \& Otte, 2000 (Shoemaker et al., 2006) and the yellow dung fly Scathophaga stercoraria (Linnaeus, 1758) (Schwarzenbach et al., 2005). In the ant Atta colombica GuérinMeneville, 1844, mating up-regulates ProPO activity, but down-regulates PO activity (Dávila et al., 2015). In the ant Lasius niger (Linnaeus, 1758), time after mating affects ProPO activity, while mating has no effect on PO activity (Dávila et al., 2015). In the ant Acromyrmex echinatior (Forel, 1899), mating down-regulates ProPo activity, but does not affect PO activity (Dávila et al., 2015). In the ground cricket Allonemobius socius (Scudder, 1877), mating up-regulates PO activity, but down-regulates haemocyte load, lytic activity and encapsulation ability (Fedorka et al., 2004). In the beetle Carabus lefebvrei Dejean, 1826, mating down-regulates both PO and lytic activities (Giglio et al., 2016). In the earwig Forficula auricularia Linnaeus, 1758, mating down-regulates PO activity when females become older, while having no influence on haemocyte load (Vogelweith et al., 2017). Mating clearly causes an immune responses in females of several insect species. However, the direction of post-mating immune responses varies among measured factors and species. Mating up-regulates female immune responses, measured as PO activity, in some species, whereas it down-regulates female immune responses in others, and in some insects there is no difference in immune responses between mated and virgin females.

\section{Post-mating immune function}

In species where mating down-regulates indicators of the immune response such as PO activity, it is concluded that mating 'corrupts' immunity (e.g., Rolff \& Siva-Jothy, 2002). However, the negative post-mating immune response does not necessarily mean that mated females become more susceptible to pathogens and/or parasites. It is important to examine whether the change caused by mating actually reduces female immune function or not. Microbial/parasitic challenge is a good method to quantify the direct effects of mating on female immune function. Here females are infected with bacteria, fungi or parasites after mating, and their survival or ability to clear the foreign pathogen is compared with that of same-aged virgin females. If the survival or clearance ability in mated females is better than in virgin females, it suggests that mating makes mated females more resistant against the specific microbe/parasite it was tested against. If the survival or clearance ability in 
mated females is worse than in virgin females, it indicates that mating makes females more susceptible to the examined pathogens and parasites. To the best of our knowledge, the effects of mating on female immune function when challenged with microbes/parasites has to date only been examined in six insect species (table 2). In five of the six species, both post-mating immune response and immune function have been tested.

An intensively studied species is the fruit fly D. melanogaster where mating increases immune gene expression. Two studies using non-pathogenic Escherichia coli (Migula, 1895) Castellani \& Chalmers, 1919 bacteria showed that there were no differences in bacterial load between mated and virgin females (McKean \& Nunney, 2005; Wigby et al., 2008; table 2). On the other hand, when infected with the pathogenic bacterium Pseudomonas aeruginosa (Schroeter, 1872) Migula, 1900, female survival varied with timing of infection after mating; females infected 3 and $9 \mathrm{~h}$ after mating had lower survival than virgin females, whereas there was no difference in survival between mated and virgin females when infected 21 and $27 \mathrm{~h}$ after mating (Fedorka et al., 2007). Since AMP immune genes are more highly expressed in females $3 \mathrm{~h}$ after mating than in virgin females in the absence of infection (table 1), Fedorka et al. (2007) suggested that female post-mating gene expression does not reflect their post-mating immune defence to bacteria.

Short \& Lazzaro (2010) infected D. melanogaster females with four different pathogenic bacteria, Providencia rettgeri (Hadley et al., 1918) Brenner et al., 1978, Pr. alcalifaciens (de Salles Gomes, 1944) Ewing, 1962, Ps. aeruginosa and Enterococcus faecalis (Andrewes \& Horder, 1906) Schleifer \& Kilpper-Bälz, 1984 at 2-3 $\mathrm{h}$ after mating, and compared the survival and ability to clear the bacterial infection between mated and virgin females for each bacterial infection. Mated females infected with Pr. rettgeri or Pr. alcalifaciens had lower survival than virgin females, and the bacterial load of mated females was higher than that of virgin females. On the other hand, when infected with Ps. aeruginosa or En. faecalis, there was no difference in survival or bacterial load between mated and virgin females (Short \& Lazzaro, 2010). The result of Ps. aeruginosa is inconsistent with the findings of Fedorka et al. (2007) who also used Ps. aeruginosa as a pathogen. The effect of mating on female immune function is likely to depend on the pathogenic strain or species used (Short \& Lazzaro, 2010) and genetic variation in host resistance (e.g., Tinsley et al., 2006; Kutzer et al., 2018). Short et al. (2012) only used Pr. rettgeri and quantified the effects of mating on survival and bacterial load. To determine how long mating impacted on subsequent immune function, they infected D. melanogaster females with Pr. rettgeri at different time points after mating (table 2). Moreover, they simultaneously measured bacterial load and transcriptional levels of several AMP genes at different time points after infection to examine any potential association. The survival of mated females was lower than that of virgin females even when infected $26.5 \mathrm{~h}$ after mating, and the bacterial load of mated females was significantly higher than that of virgin females when infected within 


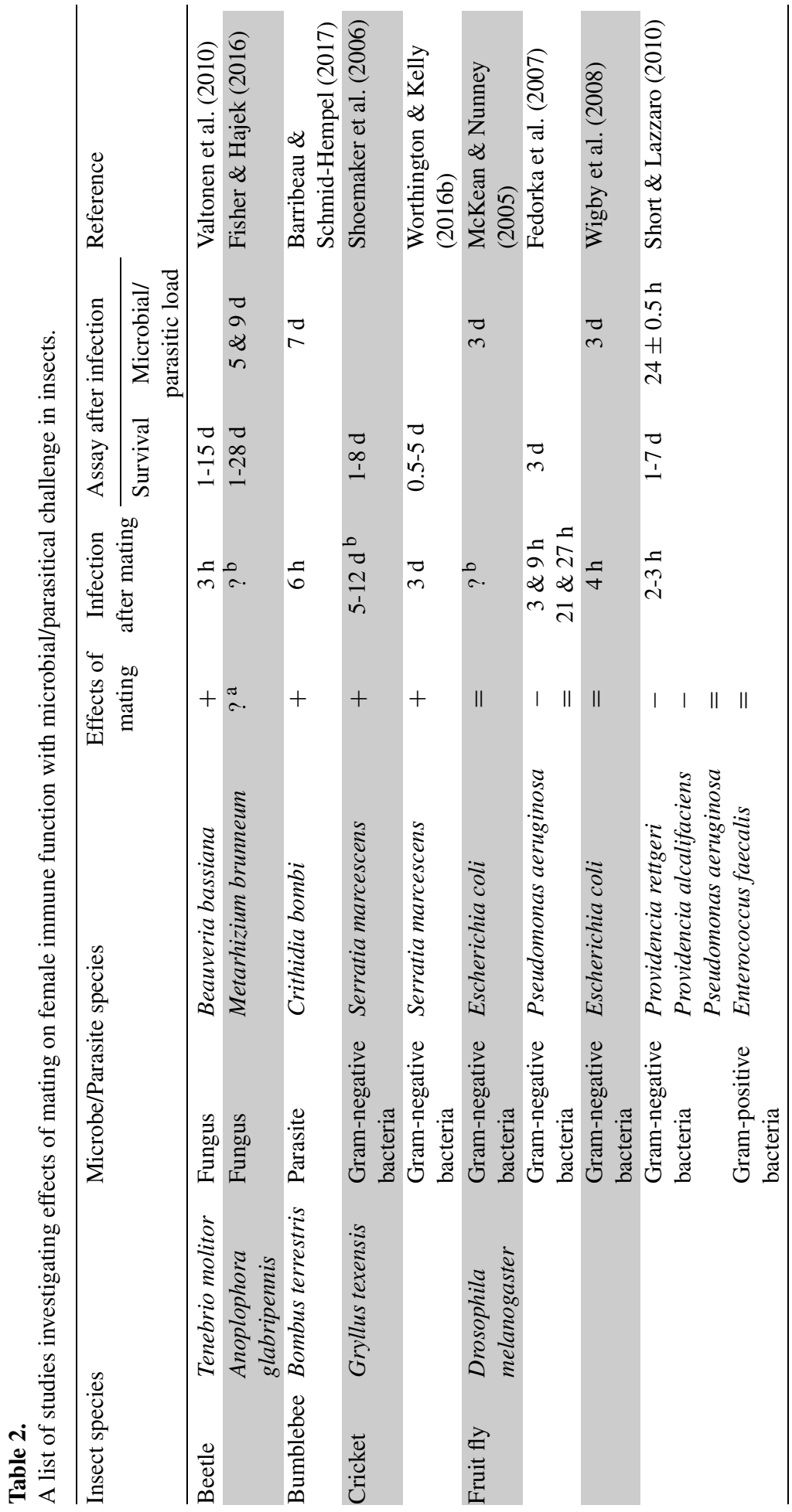




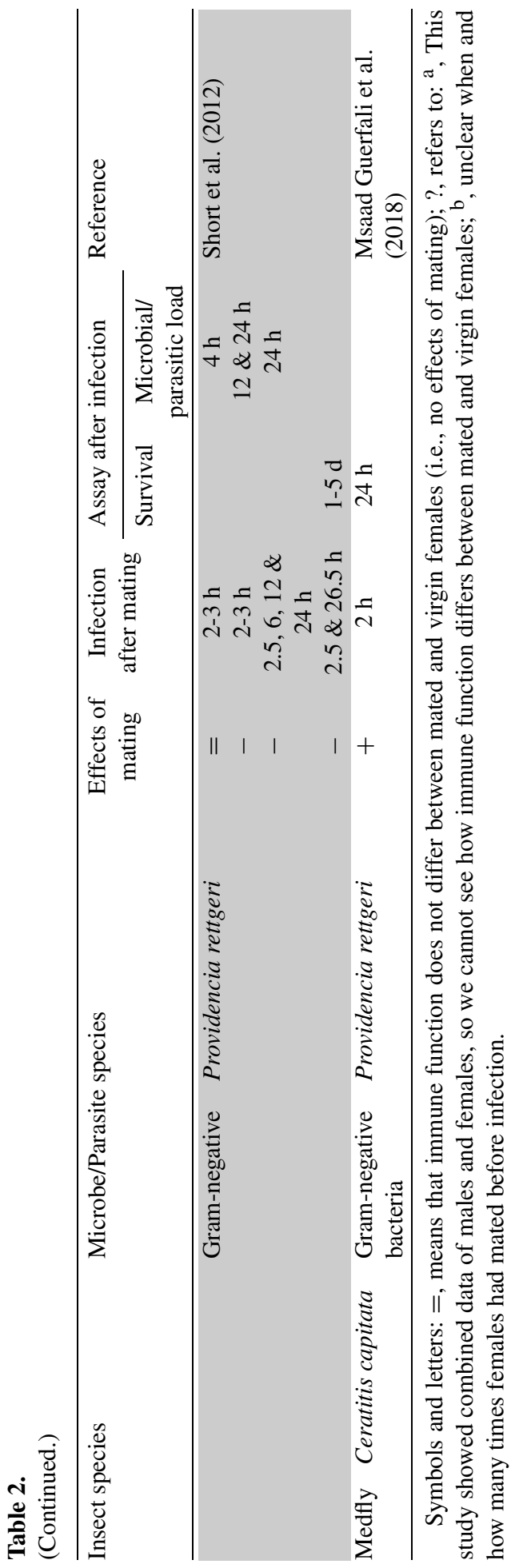


$24 \mathrm{~h}$ after mating (Short et al., 2012). These results indicate that the effect of mating on immune function continued for at least $24 \mathrm{~h}$ after mating in D. melanogaster. The transcriptional levels of AMP genes were lower in mated than in virgin females at 4 and $12 \mathrm{~h}$ after infection, but they were higher in mated females than in virgin females at $24 \mathrm{~h}$ after infection. While the bacterial load did not differ $4 \mathrm{~h}$ after infection, it was higher in mated females 12 and $24 \mathrm{~h}$ after infection compared to virgin females (Short et al., 2012). The authors suggested that the lower early AMP gene expression in mated females may have contributed to the observed increase in bacterial load. Short et al. (2012) also demonstrated that male seminal fluids reduced female immune function and that female egg production also contributed towards a reduction in their immune function. They therefore concluded that the reduction in immune function represents a cost of mating in females.

In contrast, mated females of the medfly C. capitata infected with Pr. rettgeri $2 \mathrm{~h}$ after mating survived better than virgin females (Msaad Guerfali et al., 2018). Similarly, female $G$. texensis crickets had higher survival than virgin females when infected with the bacterium Serratia marcescens Bizio, 1823 at more than three days after mating (Shoemaker et al., 2006; Worthington \& Kelly, 2016a). Mated females of the mealworm beetle T. molitor exposed to Beauveria bassiana (Bals.-Criv.) Vuill. fungus spores $3 \mathrm{~h}$ after mating also survived better than virgin females (Valtonen et al., 2010). Female B. terrestris bumblebees orally infected with the intestinal gut parasite Crithidia bombi Gorbunov, 1987 at $6 \mathrm{~h}$ after mating had lower number of parasite cells than virgin females at seven days after infection (Barribeau \& Schmid-Hempel, 2017). Thus, mated females are more resistant to the pathogens or parasites than virgin females in these four species: $C$. capitata medflies, G. texensis crickets, $T$. molitor beetles and $B$. terrestris bumblebees.

There is one interesting study in addition to those listed in table 2 . The antibacterial activity of the haemolymph of uninfected $F$. paralugubris ant females was measured at $36 \mathrm{~h}$ and seven days after mating (Castella et al., 2009). In this assay, instead of infecting females directly, the haemolymph solution was dropped on a culture medium containing live bacteria. The zone where bacterial growth had been inhibited was compared between mated and virgin females. While there was no difference at $36 \mathrm{~h}$ after mating, the haemolymph of mated females had higher antibacterial inhibition ability than that of virgin females at seven days after mating (Castella et al., 2009). This implies that mated females of $F$. paralugubris may become more resistant to bacteria at a later time point after mating.

Microbial/parasitic challenges show either that mating reduces female immune function against some, but not all, bacteria (D. melanogaster flies) or that mating enhances female immune function to foreign substances (C. capitata medflies, $G$. texensis crickets, T. molitor beetles and B. terrestris bumblebees and perhaps $F$. paralugubris ants). Below, we discuss why female post-mating immune function does not always match measured immune response and why there are differences in female post-mating immune function among species. 


\section{When and what do we measure for immunity?}

As shown above, female post-mating immune responses do not always match the consequences of immune function. Mating induces the expression of AMP genes in D. melanogaster flies, whereas mated females are sometimes more susceptible to pathogens and survived worse than virgin females. While mating reduces PO activity in T. molitor beetles, mated females survived better than virgin females. In G. texensis crickets, although PO activity is not changed following mating, mated females survived better than virgin females. In C. capitata medflies, mating only modestly activates the expression of immune genes, but mated females survived better than virgin females. Only in B. terrestris bumblebees, female post-mating immune response and the consequence of immune function positively correlated. In terms of immunity, mating appears to be costly for $D$. melanogaster females but not for other insects. Why are there such differences among species? Below, we discuss some possibilities for these differences focusing on potential disparities in the methodology used.

In microbial/parasitic challenges, there are two different time frames: the time between mating and experimental infection and the time between infection and measuring female survival or resistance. A negative effect of mating on female immune function was still observed in female D. melanogaster infected with $\mathrm{Pr}$. rettgeri 24 and $26.5 \mathrm{~h}$ after mating (Short et al., 2012) and infected with Ps. aeruginosa $9 \mathrm{~h}$ after mating (Fedorka et al., 2007). In contrast, there were no observed negative effects of mating on female survival when infected with Ps. aeruginosa at 21 and $27 \mathrm{~h}$ after mating (Fedorka et al., 2007). In G. texensis crickets where mating enhances female survival, females were infected with bacteria more than three days after mating (Shoemaker et al., 2006; Worthington \& Kelly, 2016a). If females are infected later after mating in D. melanogaster, the results may be different. Furthermore, even when the timing of infection is similar, the use of different microbial/parasite species may generate different results. In T. molitor beetles, for example, the timing of infection was $3 \mathrm{~h}$ after mating (Valtonen et al., 2010), which is similar to that in D. melanogaster flies injected with bacteria (Short \& Lazzaro, 2010; Short et al., 2012). However, the beetle females were exposed to fungus spores. Normally, fungal spores attached on the surface of insects germinate, penetrate the cuticle, and then reach the haemolymph (Pedrini, 2017). Thus, it is likely to take more time for fungi to affect host fitness than for bacteria injected directly into the haemolymph. McKean \& Nunney (2005) and Wigby et al. (2008) did not detect any effects of mating on female $D$. melanogaster bacterial load at three days after infection. This finding may be explained by the use of a non-pathogenic E. coli bacterium, but also because of the timing of measuring bacterial load. It is possible that the peak of increase in E. coli's bacterial load might have been missed. As bacteria, fungi and parasites activate different immune pathways of the hosts (Gillespie et al., 1997; Lemaitre \& Hoffmann, 2007), the time required for immune function can also vary among pathways. 
In D. melanogaster, moreover, the time points of infecting females with bacteria often overlap the period when the expression of immune genes is being induced by mating per se. Infecting flies with bacteria is normally achieved by stabbing the thorax/abdomen with a thin needle (Neyen et al., 2014). However, this piercing can itself induce expression of AMP genes, without any need for pathogen transfer (Wigby et al., 2008). This may consequently also influence female immune function, but we do not know how piercing affects and potentially interacts with the expression of immune genes already activated by mating. To exclude the piercing effect from immune challenges, other methods need to be considered for inducing infection. In the case of $B$. terrestris, although females were infected with parasites $6 \mathrm{~h}$ after mating, there was no significant effect of the parasites on immune gene expression $18 \mathrm{~h}$ after infection (Barribeau \& Schmid-Hempel, 2017). In this case they were orally infected. Although microbial/parasitic injection is a useful method to quantify the direct effects of mating on female immune function, an appropriate method that in itself does not contribute to the observed immune response should ideally be used.

In T. molitor beetles, mating down-regulates PO activity (Rolff \& Siva-Jothy, 2002), while another study found mating enhances female survival (Valtonen et al., 2010) (tables 1 and 2). In G. texensis crickets, $P O$ activity and female survival are not correlated (Shoemaker et al., 2006). It is possible that PO activity is not a good indicator of immune response against the tested microbial infections. Indeed, PO activity is shown to be unrelated to microbial infections in some insect species including G. texensis (reviewed in González-Santoyo \& Córdoba-Aguilar, 2012). PO is an enzyme involved in the melanisation reaction toward wounds or pathogens in invertebrates (Söderhäll \& Cerenius, 1998; González-Santoyo \& Córdoba-Aguilar, 2012; fig. 1). PO should therefore be related to immune function against pathogens other than microbes (e.g., Miller \& Cotter, 2017). In other species listed in table 1, PO and lytic activities, haemocyte load and encapsulation ability were measured as indicators of immune response. In order to investigate effects of mating on female immune function, it is important to know which immune response is relevant to the target immune function to be quantified (Adamo, 2004).

There are likely to be several potential factors influencing the consequences of microbial/parasitic challenges to female insects. In particular, we need to consider the timing of post-mating infection and the timing of the actual measurements. Deciding on the timing of infection will depend on what we aim to investigate. If we are interested in examining ongoing changes of the effect of mating on female immune function, infection should be done at a point right after mating. In this case, we then need to consider whether the infection methods chosen may affect female post-mating immune response or not. Determining the timing of measurements will rely on which pathogen/parasite is used for the immune challenge. Here, we already need to understand female post-mating immune responses to the pathogen/parasite in the target species. However, it is unlikely that potential disparities in the methodology used will explain all observed differences in female post-mating immunity. 
For example, females of the medfly $C$. capitata infected with Pr. rettgeri 2 h after mating survived better than virgin females (Msaad Guerfali et al., 2018) unlike what was observed in D. melanogaster (Short et al., 2012).

\section{Impact of differences in mating}

The biology of mating varies dramatically among species. It is likely that mating imposes costs on female immunity in some insect species but not in others because of underlying differences related to their mating biology. Here, we focus on mating systems and discuss the possibility that different mating systems impose different potential impact of mating on female immunity.

Mating systems differ among species: females of some species mate only once in their life (monandry), so the male they mate with is assured of fathering all offspring and post-mating conflict between male and female is likely to be low (Hosken et al., 2009). In other species, females mate with multiple males (polyandry), potentially generating conflicts between males and the female over which sperm are used to fertilise her eggs and the number of matings by the female (Kokko et al., 2014). Typically, males from polyandrous mating systems are adapted to high levels of sperm competition. In addition to sperm, males transfer seminal fluid proteins to females during copulation, which changes female physiology (Avila et al., 2011). Male seminal fluid proteins that enhance male fertilisation success can be costly to females and can cause sexual conflict over female mating (Edward et al., 2014). In polyandrous $D$. melanogaster flies for example, seminal components including the sex peptide (SP) reduce not only female sexual receptivity (Chen, 1991), stimulate egg maturation, hunger and oviposition, but can also reduce female longevity (Chapman et al., 1995). SP activates immune gene expression in mated D. melanogaster females (Peng et al., 2005; Domanitskaya et al., 2007; Wigby et al., 2008), which can reduce female immune function against some bacterial infections (Short et al., 2012; and see discussion above). Male seminal components therefore appear to down-regulate immune function of $D$. melanogaster females. If mated females refrain from remating because of their reduced immune function, fertilisation success of the initial male would be enhanced. In polyandrous species where sexual conflict is intense, males may be selected to reduce female post-mating immune function (Morrow \& Innocenti, 2012).

Females of $C$. capitata medflies, $T$. molitor beetles and $G$. texensis crickets mate multiple times (Nakagawa et al., 1971; Drnevich et al., 2001; Bonizzoni et al., 2002; Worthington \& Kelly, 2016b). After remating, C. capitata females store sperm from different males that are used to fertilize eggs (Scolari et al., 2014), which differs from Drosophila flies where sperm displacement occurs (Snook \& Hosken, 2004; Manier et al., 2010). Females of T. molitor need to remate to ensure they do not run out of sperm, which increases their fecundity (Drnevich et al., 2001). Although G. texensis females have higher chances of getting injured during multiple mating, they gain benefits of increased fecundity by replenishing ejaculates, which may 
greatly outweigh these mating costs (Worthington \& Kelly, 2016b). Worthington $\&$ Kelly (2016a) examined whether male courtship, genital contact, accessory fluids, and/or testes-derived components enhance female survival in the presence of bacterial infection and found that genital contact together with accessory fluids and testes-derived components are associated with increased female G. texensis survival. Thus, conflict over female mating does not seem to be strong in these species, despite the risk of injury to females, as mating is beneficial overall for both sexes. Females of B. terrestris bumblebees mate only once (Schmid-Hempel \& SchmidHempel, 2000). Although mating induces immune gene expression in B. terrestris females, this modification improves female resistance against parasites (Barribeau \& Schmid-Hempel, 2017). In monandrous mating systems, post-mating sexual conflict is expected to be rare as males are ensured high paternity assurance (Hosken et al., 2009). Males may be unlikely to impair female immune function after mating in species where sexual conflict is mild or absent, as any cost to female fecundity will also be borne by the mating male. To date there is limited data to examine this possibility, but mosquitos, which lack multiple mating (e.g., A. gambiae) and that have been well studied regarding mating and immunity, may be suitable organisms to test this hypothesis.

Mating system can be a driving force for evolutionary changes in both male and female reproductive traits. For example in the yellow dung fly $S$. stercoraria, males kept under polyandrous conditions for several generations evolved to invest more resources in traits that enhanced their sperm competitive success compared to males evolving under monogamous conditions (Hosken, 2001). When male reproductive traits are costly for females (e.g., seminal fluids), females are expected to evolve resistance to such traits to reduce associated costs (Holland \& Rice, 1999). In the red flour beetle Tribolium castaneum (Herbst, 1797) for example where females are naturally polyandrous, females evolving under monandrous conditions were found to reduce investment in PO activity compared to females evolving under polyandrous conditions (Hangartner et al., 2015). In other words, females appear to need to maintain investment in immunity when evolving under polyandrous conditions. This observation suggests that mating represents an immune challenge for female beetles. It is uncertain whether the immune challenge is due to sexual conflict and relative cost/benefit of multiple mating to females. If variation in the degree of sexual conflict is a major cause for the different effects of mating on female immunity we observe among insect species, there should be corresponding differences in post-mating immune function between individuals experimentally evolved under monandrous and polyandrous conditions. It will be of great interest to explore these potential consequences in evolved populations.

Polyandrous mating systems can also impact on the risk of sexually transmitted infections (Ashby \& Gupta, 2013) and parasites (Roberts et al., 2015). In general, the more females mate with multiple males (i.e., polyandry), the higher the risk of potential infections. If costs of multiple mating outweigh the benefits, females will not mate polyandrously. Females of polyandrous species may have evolved 
improved post-mating immune function in order to cope with the higher likelihood of sexually transmitted infections and parasites. This possibility gives rise to two predictions: if sexual conflict is key to shaping the effects of mating on female immunity, females of polyandrous species (where sexual conflict is expected to be greater) should show reduced post-mating immune function, whereas if sexually transmitted infections and parasites are key, females of polyandrous species should show higher post-mating immune function than those of monandrous species. To date, these possibilities remain largely untested.

\section{Conclusion and perspectives}

Does mating in general negatively affect female immune defences in insects? The answer is partly 'yes' and partly 'no', because it depends on the species and when immunity is being measured and by what methodology is being used. To date, there are insufficient numbers of studies conducted to conclusively answer this question. In addition, although we did not mention the details on copulatory wounding in this paper, this can influence the females' immune system (Reinhardt et al., 2015). We also need to consider this point in future studies.

Mating system is likely to be key to clarifying the links between immunity and mating in female insects. It is suggested that mating system has influenced the evolution of some immune genes in primates (Wlasiuk \& Nachman, 2010). It is possible that female mating frequency correlates with immune function also in insects. To test this possibility, we need to compare female post-mating immune function between individuals experimentally evolved under monandrous and polyandrous conditions. We can also quantify the impact of mating on female immune function by comparing monandrous and polyandrous species (e.g., Lizé et al., 2014). Furthermore, genetic variation in female mating frequency exists in some insect species (Wedell, 2001; Wedell et al., 2002; Simmons, 2003; Harano \& Miyatake, 2005; Price et al., 2008). By using individuals that show divergent genetically determined mating frequencies, we can investigate whether a pre-determined female mating frequency correlates with female immune function within species.

Apart from mating, nutrients can influence female immune defences. In $D$. melanogaster flies, for example, females infected with bacteria survived better when fed a low amount of sugar or an added-yeast diet than when fed a high amount of sugar (Howick \& Lazzaro, 2014) or a reduced-yeast diet (Kutzer et al., 2018). In several insect species, males provide a nuptial gift at mating, including prey items, secretions from male glands, and substances transferred in ejaculates (Thornhill \& Alcock, 1983; Vahed, 1998; Gwynne, 2008). As nuptial gifts provide additional nutrients to females, nuptial gifts may also affect female immune defences. In $G$. texensis crickets, genital contact together with accessory fluids and testes-derived components are associated with increased female survival in the presence of bacterial infection (Worthington \& Kelly, 2016a). The function of ejaculates influencing female immunity has been investigated well in the fruit fly D. melanogaster, but 
not in other species of insects. It may be a good start to use those insect species where males transfer nutrients to females during mating in order to clarify the links between female immunity and mating. To improve our understanding of the links between female immunity and mating, we need to expand our studies to include a broader range of insect taxa with varying biology.

\section{Acknowledgements}

We thank Dr. Ben Longdon for his comments on an earlier version of the manuscript and two anonymous referees for their valuable comments to improve the manuscript. KO has received funding from the European Union's Horizon 2020 research and innovation programme under the Marie Skłodowska-Curie grant agreement No 746169.

\section{References}

Adamo, S.A. (2004) How should behavioural ecologists interpret measurements of immunity? Anim. Behav., 68, 1443-1449.

Ashby, B. \& Gupta, S. (2013) Sexually transmitted infections in polygamous mating systems. Phil. Trans. R. Soc. Lond. B Biol. Sci., 368, 20120048. DOI:10.1098/rstb.2012.0048.

Avila, F.W., Sirot, L.K., LaFlamme, B.A., Rubinstein, C.D. \& Wolfner, M.F. (2011) Insect seminal fluid proteins: identification and function. Annu. Rev. Entomol., 56, 21-40.

Barribeau, S.M. \& Schmid-Hempel, P. (2017) Sexual healing: mating induces a protective immune response in bumblebees. J. Evol. Biol., 30, 202-209.

Bascuñán-García, A.P., Lara, C. \& Córdoba-Aguilar, A. (2010) Immune investment impairs growth, female reproduction and survival in the house cricket, Acheta domesticus. J. Insect Physiol., 56, 204-211.

Blanckenhorn, W.U., Hosken, D.J., Martin, O.Y., Reim, C., Teuschl, Y. \& Ward, P.I. (2002) The costs of copulating in the dung fly Sepsis cynipsea. Behav. Ecol., 13, 353-358.

Bonizzoni, M., Katsoyannos, B.I., Marguerie, R., Gulglielmino, C.R., Gasperi, G., Malacrida, A. \& Chapman, T. (2002) Microsatellite analysis reveals remating by wild Mediterranean fruit fly females, Ceratitis capitate. Mol. Ecol., 11, 1915-1921.

Butt, T.M., Wraight, S.P., Galaini-Wraight, S., Humber, R.A., Roberts, D.W. \& Soper, R.S. (1988) Humoral encapsulation of the fungus Erynia radicans (Entomophthorales) by the potato leafhopper, Empoasca fabae (Homoptera: Cicadellidae). J. Invert. Pathol., 52, 49-56.

Castella, G., Christe, P. \& Chapuisat, M. (2009) Mating triggers dynamic immune regulations in wood ant queens. J. Evol. Biol., 22, 564-570.

Chapman, T., Liddle, L.F., Kalb, J.M., Wolfner, M.F. \& Partridge, L. (1995) Cost of mating in Drosophila melanogaster females is mediated by male accessory gland products. Nature, 373, 241-244.

Chen, P.-S. (1991) Biochemistry and molecular regulation of the male accessory gland secretions in Drosophila (Diptera). Ann. Soc. Entomol. Fr., 27, 231-244.

Chen, X., Zhu, F., Lü, P., Ma, S., Nouara, A., Yang, Y. \& Chen, K. (2016) Properties of the Bombyx mori insulin-like peptide (BmILP) gene. Invertebr. Surviv. J., 13, 76-88.

Crudgington, H.S. \& Siva-Jothy, M.T. (2000) Genital damage, kicking and early death. Nature, 855856. 
Dávila, F., Cherasse, S., Boomsma, J.J. \& Aron, S. (2015) Ant sperm storage organs do not have phenoloxidase constitutive immune activity. J. Insect Physiol., 78, 9-14.

Domanitskaya, E.V., Liu, H., Chen, S. \& Kubli, E. (2007) The hydroxyproline motif of male sex peptide elicits the innate immune response in Drosophila females. FEBS J., 274, 5659-5668.

Drnevich, J.M., Papke, R.S., Rauser, C.L. \& Rutowski, R.L. (2001) Material benefits from multiple mating in female mealworm beetles (Tenebrio molitor L.). J. Insect Behav., 14, 215-230.

Edward, D.A., Stockley, P. \& Hosken, D.J. (2014) Sexual conflict and sperm competition. Cold Spring Harb. Perspect. Biol., 7, a017707. DOI:10.1101/cshperspect.a017707.

Eslin, P. \& Prevost, G. (1996) Variation in Drosophila concentration of haemocytes associated with different ability to encapsulate Asobara tabida larval parasitoid. J. Insect Physiol., 42, 549-555.

Eslin, P. \& Prévost, G. (1998) Hemocyte load and immune resistance to Asobara tabida are correlated in species of the Drosophila melanogaster subgroup. J. Insect Physiol., 44, 807-816.

Fedorka, K.M., Zuk, M. \& Mousseau, T.A. (2004) Immune suppression and the cost of reproduction in the ground cricket, Allonemobius socius. Evolution, 58, 2478-2485.

Fedorka, K.M., Linder, J.E., Winterhalter, W. \& Promislow, D. (2007) Post-mating disparity between potential and realized immune response in Drosophila melanogaster. Proc. Biol. Sci., 274, 12111217.

Fisher, J.J. \& Hajek, A.E. (2016) Influence of mating and age on susceptibility of the beetle Anoplophora glabripennis to the fungal pathogen Metarhizium brunneum. J. Invertebr. Pathol., 136, 142-148.

Giglio, A., Brandmayr, P., Cammarata, M., Cavaliere, F., Trapani, M.R. \& Giulianini, P.G. (2016) Are immune responses gender-related in Carabus lefebvrei (Coleoptera: Carabidae)? Invertebr. Surviv. J., 13, 102-110.

Gillespie, J.P., Kanost, M.R. \& Trenczek, T. (1997) Biological mediators of insect immunity. Аnnu. Rev. Entomol., 42, 611-643.

Gomulski, L.M., Dimopoulos, G., Xi, Z., Scolari, F., Gabrieli, P., Siciliano, P., Clarke, A.R., Malacrida, A.R. \& Gaasperi, G. (2012) Transcriptome profiling of sexual maturation and mating in the Mediterranean fruit fly, Ceratitis capitata. PLoS One, e30857. DOI:10.1371/journal.pone. 0030857.

González-Santoyo, I. \& Córdoba-Aguilar, A. (2012) Phenoloxidase: a key component of the insect immune system. Entomol. Exp. Appl., 142, 1-16.

Gwynne, D.T. (2008) Sexual conflict over nuptial gifts in insects. Annu. Rev. Entomol., 53, 83-101.

Hangartner, S., Michalczyk, Ł., Gage, M.J. \& Martin, O.Y. (2015) Experimental removal of sexual selection leads to decreased investment in an immune component in female Tribolium castaneum. Infect. Genet. Evol., 33, 212-218.

Harano, T. \& Miyatake, T. (2005) Heritable variation in polyandry in Callosobruchus chinensis. Anim. Behav., 70, 299-304.

Holland, B. \& Rice, W.R. (1999) Experimental removal of sexual selection reverses intersexual antagonistic coevolution and remove a reproductive load. Proc. Natl Acad. Sci. USA, 96, 5083-5088.

Hosken, D.J. (2001) Sex and death: microevolutionary trade-offs between reproductive and immune investment in dung flies. Curr. Biol., 11, R379-R380.

Hosken, D.J., Stockley, P., Tregenza, T. \& Wedell, N. (2009) Monogamy and the battle of the sexes. Annu. Rev. Entomol., 54, 361-378.

Howick, V.M. \& Lazzaro, B.P. (2014) Genotype and diet shape resistance and tolerance across distinct phases of bacterial infection. BMC Evol. Biol., 14, 56. DOI:10.1186/1471-2148-14-56. 
Hurst, G.D.D., Sharpe, R.G., Broomfield, A.H., Walker, L.E., Majerus, T.M.O., Zakharov, I.A. \& Majerus, M.E.N. (1995) Sexually transmitted disease in a promiscuous insect, Adalia bipunctata. Ecol. Entomol., 20, 230-236.

Innocenti, P. \& Morrow, E.H. (2009) Immunogenic males: a genome-wide analysis of reproduction and the cost of mating in Drosophila melanogaster females. J. Evol. Biol., 22, 964-973.

Kamimura, Y. (2007) Twin intromittent organs of Drosophila for traumatic insemination. Biol. Lett., 3, 401-404.

Kapelnikov, A., Zelinger, E., Gottlieb, Y., Rhrissorrakrai, K., Gunsalus, K.C. \& Heifetz, Y. (2008) Mating induces an immune response and developmenta switch in the Drosophila oviduct. Proc. Natl Acad. Sci. USA, 105, 13912-13917.

Knell, R.J. \& Webberley, K.M. (2004) Sexually transmitted diseases of insects: distribution, evolution, ecology and host behaviour. Biol. Rev. Camb. Philos. Soc., 79, 557-581.

Kokko, H., Klug, H. \& Jennions, M.D. (2014) Mating systems. In: D.M. Shuker \& L.W. Simmons (Eds): The Evolution of Insect Mating Systems, pp. 42-58. Oxford University Press, Oxford, UK.

Kutzer, M.A.M., Kurtz, J. \& Armitage, S.A.O. (2018) Genotype and diet affect resistance, survival, and fecundity but not fecundity tolerance. J. Evol. Biol., 31, 159-171.

Lawniczak, M.K., Barnes, A.I., Linklater, J.R., Boone, J.M., Wigby, S. \& Chapman, T. (2007) Mating and immunity in invertebrates. Trends Ecol. Evol., 22, 48-55.

Lawniczak, M.K.N. \& Begun, D.J. (2004) A genome-wide analysis of courting and mating responses in Drosophila melanogaster females. Genome, 47, 900-910.

Lazzaro, B.P. \& Little, T.J. (2009) Immunity in a variable world. Philos. Trans. R. Soc. Lond. B Biol. Sci., 364, 15-26.

Lemaitre, B. \& Hoffmann, J. (2007) The host defense of Drosophila melanogaster. Annu. Rev. Immunol., 25, 697-743.

Lizé, A., Price, T.A., Heys, C., Lewis, Z. \& Hurst, G.D. (2014) Extreme cost of rivalry in a monandrous species: male-male interactions result in failure to acquire mates and reduced longevity. Proc. Biol. Sci., 281, 20140631. DOI:10.1098/rspb.2014.0631.

Lochmiller, R.L. \& Deerenberg, C. (2000) Trade-offs in evolutionary immunology: just what is the cost of immunity. Oikos, 88, 87-98.

Mack, P.D., Kapelnikov, A., Heifetz, Y. \& Bender, M. (2006) Mating-responsive genes in reproductive tissues of female Drosophila melanogaster. Proc. Natl Acad. Sci. USA, 103, 10358-10363.

Manier, M.K., Belote, J.M., Berben, K.S., Novikov, D., Stuart, W.T. \& Pitnick, S. (2010) Resolving mechanisms of competitive fertilization success in Drosophila melanogaster. Science, 328, 354357.

McGraw, L.A., Gibson, G., Clark, A.G. \& Wolfner, M.F. (2004) Genes regulated by mating, sperm, or seminal proteins in mated female Drosophila melanogaster. Curr. Biol., 14, 1509-1514.

McKean, K.A. \& Nunney, L. (2005) Bateman's principle and immunity: phenotypically plastic reproductive strategies predict changes in immunological sex differences. Evolution, 59, 1510-1517.

Miller, C.V.L. \& Cotter, S.C. (2017) Pathogen and immune dynamics during maturation are explained by Bateman's Principle. Ecol. Entomol., 42(S1), 28-38.

Morrow, E.H. \& Innocenti, P. (2012) Female postmating immune responses, immune system evolution and immunogenic males. Biol. Rev. Camb. Philos. Soc., 87, 631-638.

Msaad Guerfali, M., Djobbi, W., Charaabi, K., Hamden, H., Fadhl, S., Marzouki, W., Dhaouedi, F. \& Chevrier, C. (2018) Evaluation of Providencia rettgeri pathogenicity against laboratory Mediterranean fruit fly strain (Ceratitis capitata). PLoS One, 13, e0196343. DOI:10.1371/journal.pone. 0196343. 
Nakagawa, S., Farias, G.J., Suda, D., Cunningham, R.T. \& Chambers, D.L. (1971) Reproduction of the Mediterranean fruit fly: frequency of mating in the laboratory. Ann. Entomol. Soc. Am., 64, 949-950.

Neyen, C., Bretscher, A.J., Binggeli, O. \& Lemaitre, B. (2014) Methods to study Drosophila immunity. Methods, 68, 116-128.

Pedrini, N. (2017) Molecular interactions between entomopathogenic fungi (Hypocreales) and their insect host: perspectives from stressful cuticle and hemolymph battlefields and the potential of dual RNA sequencing for future studies. Fungal Biol., 122, 538-545.

Peng, J., Zipperlen, P. \& Kubli, E. (2005) Drosophila sex-peptide stimulates female innate immune system after mating via Toll and Imd pathways. Curr. Biol., 15, 1690-1694.

Price, T.A.R., Hodgson, D.J., Lewis, Z., Hurst, G.D.D. \& Wedell, N. (2008) Selfish genetic elements promote polyandry in a fly. Science, 322, 1241-1243.

Ragan, E.J., An, C., Jiang, H. \& Kanost, M.R. (2009) Roles of haemolymph proteins in antimicrobial defences of Manduca sexta. In: J. Rolff \& S.E. Reynolds (Eds): Insect Infection and Immunity: Evolution, Ecology, and Mechanisms, pp. 34-48. Oxford University Press, Oxford, UK.

Reinhardt, K., Anthes, N. \& Rolanda, L. (2015) Copulatory wounding and traumatic insemination. Cold Spring Harb. Perspect. Biol., 7, a017582. DOI:10.1101/cshperspect.a017582.

Roberts, K.E., Evison, S.E.F., Baer, B. \& Hughes, W.O.H. (2015) The cost of promiscuity: sexual transmission of Nosema microsporidian parasites in polyandrous honey bees. Sci. Rep., 5, 10982. DOI:10.1038/srep10982.

Rogers, D.W., Whitten, M.M., Thailayil, J., Soichot, J., Levashina, E.A. \& Catteruccia, F. (2008) Molecular and cellular components of the mating machinery in Anopheles gambiae females. Proc. Natl Acad. Sci. USA, 105, 19390-19395.

Rolff, J. \& Reynolds, S.E. (2009) Insect Infection and Immunity: Evolution, Ecology, and Mechanisms. Oxford University Press, Oxford, UK.

Rolff, J. \& Siva-Jothy, M.T. (2002) Copulation corrupts immunity: a mechanism for a cost of mating in insects. Proc. Natl Acad. Sci. USA, 99, 9916-9918.

Schmid-Hempel, P. (2005) Evolutionary ecology of insect immune defenses. Annu. Rev. Entomol., 50, 529-551.

Schmid-Hempel, R. \& Schmid-Hempel, P. (2000) Female mating frequencies in Bombus spp. from central Europe. Insectes Soc., 47, 36-41.

Schwarzenbach, G.A., Hosken, D.J. \& Ward, P.I. (2005) Sex and immunity in the yellow dung fly Scathophaga stercoraria. J. Evol. Biol., 18, 455-463.

Schwenke, R.A. \& Lazzaro, B.P. (2017) Juvenile hormone suppresses resistance to infection in mated female Drosophila melanogaster. Curr. Biol., 27, 596-601.

Schwenke, R.A., Lazzaro, B.P. \& Wolfner, M.F. (2016) Reproduction-immunity trade-offs in insects. Annu. Rev. Entomol., 61, 239-256.

Scolari, F., Yuval, B., Gomulski, L.M., Schetelig, M.F., Gabrieli, P., Bassetti, F., Wimmer, E.A., Malacrida, A.R. \& Gasperi, G. (2014) Polyandry in the medfly - shifts in paternity mediated by sperm stratification and mixing. BMC Genet., 15(Suppl. 2), S10. DOI:10.1186/1471-2156-15-S2S10.

Sheldon, B.C. \& Verhulst, S. (1996) Ecological immunology: costly parasite defences and trade-offs in evolutionary ecology. Trends Ecol. Evol., 11, 317-321.

Shoemaker, K.L., Parsons, N.M. \& Adamo, S.A. (2006) Mating enhance parasite resistance in the cricket Gryllus texensis. Anim. Behav., 71, 371-380.

Short, S.M. \& Lazzaro, B.P. (2010) Female and male genetic contributions to post-mating immune defence in female Drosophila melanogaster. Proc. Biol. Sci., 277, 3649-3657. 
Short, S.M., Wolfner, M.F. \& Lazzaro, B.P. (2012) Female Drosophila melanogaster suffer reduced defense against infection due to seminal fluid components. J. Insect Physiol., 58, 1192-1201.

Shuker, D.M. \& Simmons, L.W. (2014) The Evolution of Insect Mating Systems. Oxford University Press, Oxford, UK.

Simmons, L.W. (2003) The evolution of polyandry: patterns of genotypic variation in female mating frequency, male fertilization success and a test of the sexy-sperm hypothesis. J. Evol. Biol., 16, 624-634.

Smith, G. \& Dobson, A.P. (1992) Sexually transmitted diseases in animals. Parasitol. Today, 8, 159166.

Snook, R.R. \& Hosken, D.J. (2004) Sperm death and dumping in Drosophila. Nature, 428, 939-941.

Söderhäll, K. \& Cerenius, L. (1998) Role of the prophenoloxidase-activating system in invertebrate immunity. Curr. Opin. Immunol., 10, 23-28.

Soller, M., Bownes, M. \& Kubli, E. (1999) Control of oocyte maturation in sexually mature Drosophila females. Dev. Biol., 280, 337-351.

South, A. \& Lewis, S.M. (2011) The influence of male ejaculate quantity on female fitness: a metaanalysis. Biol. Rev. Camb. Philos. Soc., 86, 299-309.

Thornhill, R. \& Alcock, J. (1983) The Evolution of Insect Mating Systems. Harvard University Press, Cambridge, MA, USA.

Tinsley, M.C., Blanford, S. \& Jiggins, F. (2006) Genetic variation in Drosophila melanogaster pathogen susceptibility. Parasitology, 132, 767-773.

Vahed, K. (1998) The function of nuptial feeding in insects: a review of empirical studies. Biol. Rev. Camb. Philos. Soc., 73, 43-78.

Valtonen, T.M., Viitaniemi, H. \& Rantala, M.J. (2010) Copulation enhances resistance against an entomopathogenic fungus in the mealworm beetle Tenebrio molitor. Parasitology, 137, 985-989.

Vogelweith, F., Foitzik, S. \& Meunier, J. (2017) Age, sex, mating status, but not social isolation interact to shape basal immunity in a group-living insect. J. Insect Physiol., 103, 64-70.

Wedell, N. (2001) Female remating in butterflies: interaction between female genotype and nonfertile sperm. J. Evol. Biol., 14, 746-754.

Wedell, N., Wiklund, C. \& Cook, P.A. (2002) Monandry and polyandry as alternative lifestyles in a butterfly. Behav. Ecol., 13, 450-455.

Whitlow, C.B. (2004) Bacterial sexually transmitted diseases. Clin. Colon Rectal. Surg., 17, 209-214.

Wigby, S., Domanitskaya, E.V., Choffat, Y., Kubli, E. \& Chapman, T. (2008) The effect of mating on immunity can be masked by experimental piercing in female Drosophila melanogaster. J. Insect Physiol., 54, 414-420.

Wlasiuk, G. \& Nachman, M.W. (2010) Promiscuity and the rate of molecular evolution at primate immunity genes. Evolution, 64, 2204-2220.

Worthington, A.M. \& Kelly, C.D. (2016a) Females gain survival benefits from immune-boosting ejaculates. Evolution, 70, 928-933.

Worthington, A.M. \& Kelly, C.D. (2016b) Direct costs and benefits of multiple mating: are high female mating rates due to ejaculate replenishment? Behav. Proc., 124, 115-122.

Zhang, L.-J. \& Gallo, R.L. (2016) Antimicrobial peptides. Curr. Biol., 26, R14-R19.

Zuk, M. \& Stoehr, A.M. (2002) Immune defense and host life history. Am. Nat., 160(Suppl. 4), S9S22. 